\title{
Some new insights into real convergence in MENA countries' regional areas: a spatial econometric analysis
}

\author{
Nicolas Péridy $^{1 *} \cdot$ Mohamed Hazem $^{2} \cdot$ Marc Brunetto $^{1}$ \\ ${ }^{1}$ Université de Toulon, France \\ ${ }^{2}$ Université de Sousse, Tunisia
}

Received: 10 June 2013

Revised: 6 September 2013

Accepted: 12 September 2013

\begin{abstract}
This paper proposes an analysis of real income convergence in MENA countries for more than 800 disaggregated regional areas. A spatial analysis is implemented in order to take into account the spatial interactions of GDP per capita in these areas. Moreover, a betaconvergence equation (absolute and conditional) is estimated with spatially correlated errors and spatial lag models. The conditional model also includes original climate variables (temperature and precipitations) at the same geographical level. Results show that the hypothesis of regional convergence is generally accepted in most MENA countries, with the exception of Egypt and Morocco. However, the convergence process is slow and climate change in MENA countries is likely to further slowdown this process.
\end{abstract}

Keywords: convergence, MENA countries, spatial econometrics

JEL Classification Codes: O47, O53, O57

\section{Introduction}

Real convergence in Middle East and North African (MENA) countries has increasingly become a major concern for both economic and political reasons. First, the persisting GDP per capita gap between the two sides of the Mediterranean Sea is likely to increase migration pressure and political tensions between the South and the North. Second, the problem of regional inequalities within MENA countries in terms of living standards is also central for explaining political instability in these territories. In recent years, the emergence of Arab revolutions has further highlighted the need for promoting economic development in MENA countries at regional level.

*Corresponding author. E-mail: nicolas.peridy@univ-tln.fr.

Citation: Péridy, N., Hazem, M. and Brunetto, M. (2013) Some new insights into real convergence in MENA countries' regional areas: a spatial econometric analysis, Economics and Business Letters, 2(4), 150-160. 
The literature related to real convergence in these countries is still scarce and incomplete. Using data at country level, Guétat and Serratino (2007), Hammouda et al. (2009), Erlat (2007) and Pesaran (2007) show that the convergence process is not uniform over time and across countries. For example, there may be some differences between oil and non-oil countries (Rey, 2005) or the existence of convergence clubs as argued by Guétat and Serratino (2007). In any case, the convergence hypothesis is not clearly established for Mediterranean countries.

Some other studies focus on the convergence of MENA countries with regard to other countries' GDP per capita. For example, Péridy and Bagoulla (2012) show that only a few MENA countries, such as Tunisia, are clearly converging toward EU income levels. On the other hand, some other countries, such as Algeria and Jordan, are diverging. A few other studies choose another income reference threshold, such as Southern EU countries (Guétat and Serratino, 2010). Using time series tests for income convergence, these authors conclude that there is generally no convergence of MENA countries toward Southern EU countries levels, with the exception of Tunisia and Egypt.

One striking feature is the lack of literature at regional level. However, it seems crucial to consider that MENA countries' GDP and growth are not uniform across regions. Consequently, convergence must be studied at disaggregated geographical areas. This study contributes to filling this lack of literature by analyzing convergence in MENA countries for more than 800 disaggregated regional areas. This analysis is based on the GEcon 3.3 dataset (Yale University) which provides data on Gross Cell Products. A second contribution is the application of spatial analysis in order to take into account the spatial interactions concerning GDP in these areas. For this purpose, a $\beta$-convergence equation (absolute and conditional) is estimated with spatially correlated errors and spatial lag models. Third, the conditional model includes original climate variables (temperature and precipitations) at the same geographical level. The introduction of these variables in growth models is justified by the emerging literature on the relationship between climate and income which shows that the rise in temperature and the decrease in precipitations have a negative impact on growth especially when countries are dependent on agriculture (Pindyck, 2010).

This article is organized as follows. Section 2 presents a preliminary analysis of GDP per capita in MENA countries at regional level. Section 3 is dedicated to the implementation of the $\beta$-convergence model and the description of data, while section 4 discusses the results of the estimations.

\section{A geographical overview of "gross regional product" in MENA regional areas}

Figure 1 shows the regional units considered and the corresponding GDP per capita. It is based on the dataset developed in the framework of the G-Econ research project (Yale University), which is devoted to developing a geophysical based dataset on economic activity for the world. The current data set (GEcon 3.3) is now publicly available and covers "gross cell product" for all regions, which includes 27,500 terrestrial grid cells for four years (1990, 1995, 2000, and 2005). The basic metric is the regional equivalent of gross domestic product. Gross cell product (GCP) is measured at a 1-degree longitude by 1-degree latitude resolution at a global scale. The advantage of this dataset is that the geographical units (approximately $100 \mathrm{~km}$ by $100 \mathrm{~km}$ ) are somewhat smaller than the size of the major sub-national political entities for most large countries and approximately the same size as the second level political entities in most countries, e.g., departments in France (for all details, refer to http://gecon.yale.edu). The data downloaded for MENA countries provide the following number of cells: Algeria: 255; Egypt: 106; Israel: 9; Jordan: 17; Lebanon: 4; Libya: 171: Morocco: 81; Syria: 33; Tunisia: 30; Turkey: 102. Overall, 808 cells are available. 
Figure 1. The Gross Cell Products in MENA countries' regional units (2005)

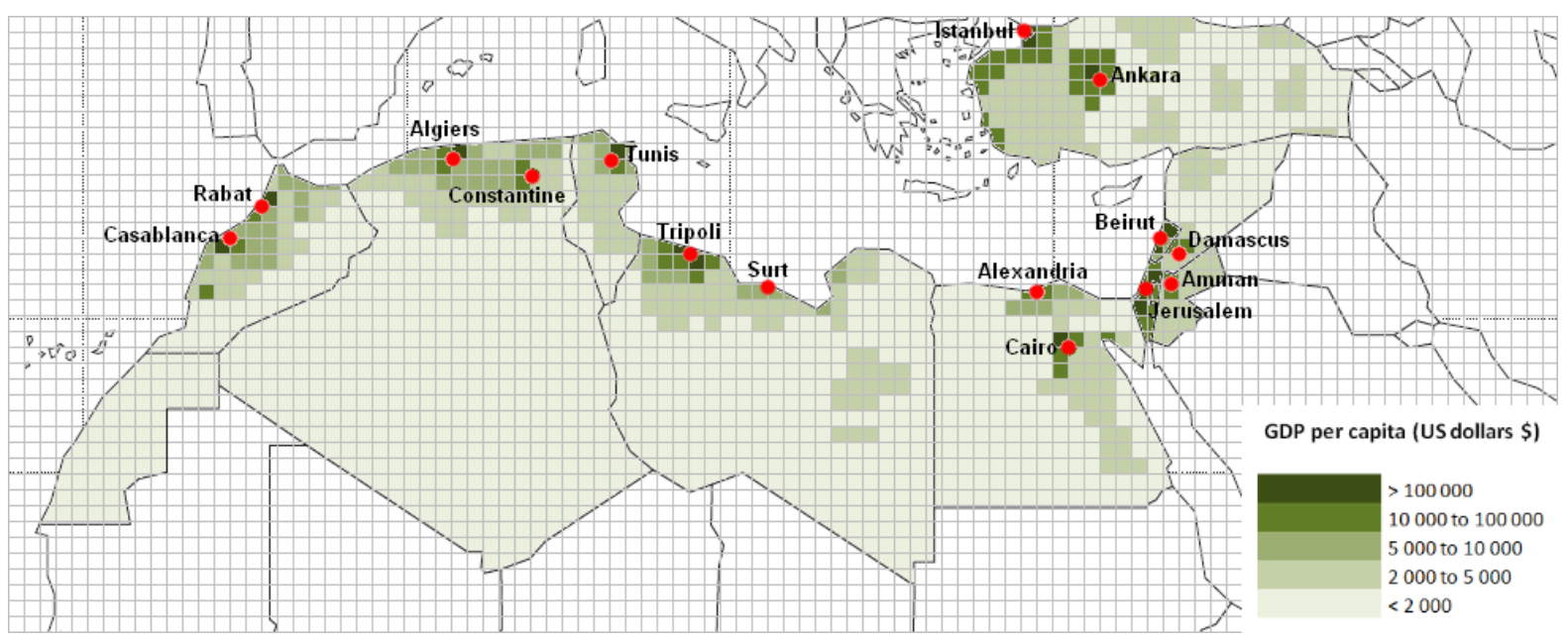

Source: own calculations from GEcon 3.3 database

This figure clearly suggests that the geographical areas with high GDP per capita are surrounded by areas which also show high GDP per capita. This is particularly striking for regional areas near big cities. This is an indication that there are spatial interactions for real income in MENA countries. These spatial interactions can be further specified and tested with the indexes developed by Moran and Geary. These tests, which are commonly used in the literature, measure the intensity of the spatial interactions between each pair of regions $i$ and $j$. A more recent test is also added: this is the global APLE statistic developed by Li et al. (2007). This is an Approximate Profile-Likelihood Estimator of the SAR model's spatial dependence parameter. It better fits the spatial dependence parameter when this parameter is not close to zero. Table 1 provides these statistics by using the average GDP per capita in each geographical area for the period 1990-2005. Countries with a small number of regional units (Tunisia, Israel, Jordan and Syria) have been aggregated in two separate larger regional units: Mashrek ${ }^{1}$ and Maghreb $^{2}$. The spatial weights matrix is based on the inverse distance between the regional units $\mathrm{i}$ and $\mathrm{j}$. Results show that all Moran and Geary statistics are positive and significant at $1 \%$ level. This suggests that GDP per capita in MENA countries are positively spatially correlated, i.e. the regional areas with high (low) GDP are located near regional areas which also show high (low) GDP. The APLE statistic correlates this result by showing positive values. As a sensitivity analysis, Tables A.1 and A.2 in the Appendix show the statistics corresponding to other types of spatial weight matrix: the second-order contiguity matrix and the nearest neighbor matrix. Results are similar to those found with the inverse distance matrix.

\footnotetext{
${ }^{1}$ Egypt, Israel, Jordan, Lebanon and Syria.

${ }^{2}$ Algeria, Libya, Morocco and Tunisia.
} 
Table 1. Moran, Geary and APLE statistics based on the inverse distance matrix

\begin{tabular}{|c|c|c|c|c|}
\hline & $\begin{array}{l}\text { Number of } \\
\text { regional units }\end{array}$ & Moran & $\overline{\text { Geary }}$ & $\overline{~ A P L E}$ \\
\hline $\begin{array}{l}\text { All areas } \\
\text { (MENA) }\end{array}$ & 808 & $\begin{array}{l}0.4753 \\
\left(2.2 .10^{-11}\right)^{* * *}\end{array}$ & $\begin{array}{l}0.4890 \\
\left(2.2 .10^{-12}\right)^{* * *}\end{array}$ & 0.5612 \\
\hline Algeria & 255 & $\begin{array}{l}0.1299 \\
\left(2.09 .10^{-10}\right)^{* * *}\end{array}$ & $\begin{array}{l}0.7134 \\
\left(6.79 .10^{-10}\right)^{* * * *}\end{array}$ & 0.4739 \\
\hline Egypt & 106 & $\begin{array}{l}0.1406 \\
(0.0007)^{* * * *}\end{array}$ & $\begin{array}{l}0.8189 \\
(0.003)^{* * *}\end{array}$ & 0.3945 \\
\hline Libya & 71 & $\begin{array}{l}0.3070 \\
\left(2.2 .10^{-7}\right)^{* * *}\end{array}$ & $\begin{array}{l}0.7047 \\
\left(1.04 .10^{-8}\right)^{* * *}\end{array}$ & 0.6045 \\
\hline Morocco & 81 & $\begin{array}{l}0.1406 \\
\left(2.2 .10^{-16}\right)^{* * *}\end{array}$ & $\begin{array}{l}0.4754 \\
\left(2.2 .10^{-16}\right)^{* * *}\end{array}$ & 0.4512 \\
\hline Turkey & 102 & $\begin{array}{l}0.7751 \\
\left(2.2 .10^{-16}\right)^{* * *}\end{array}$ & $\begin{array}{l}0.1862 \\
\left(2.2 .10^{-16}\right)^{* * *}\end{array}$ & 0.8529 \\
\hline Mashrek & 171 & $\begin{array}{l}0.3746 \\
\left(2.01 .10^{-11}\right)^{\text {**** }}\end{array}$ & $\begin{array}{l}0.6101 \\
\left(3.65 .10^{-10}\right)^{\text {*** }}\end{array}$ & 0.6214 \\
\hline Maghreb & 537 & $\begin{array}{l}0.2179 \\
\left(2.2 .10^{-16}\right)^{* * *}\end{array}$ & $\begin{array}{l}0.6644 \\
\left(3.31 .10^{-16}\right)^{* * *}\end{array}$ & 0.4519 \\
\hline
\end{tabular}

Note: $* * *, * *, *$ : significant at respectively $1 \%, 5 \%$ and $10 \%$ level

With regard to the APLE statistics, standard errors are not provided in the R-package. In fact, since these statistics are greater than the Moran ones and since the Moran statistics are all significant, then the APLE is necessarily significant (it is is more efficient when the dependence parameter is not close to zero which is the case here).

\section{Real convergence of MENA countries' regional areas: the model and data}

Given the data available at this disaggregated geographical level, real convergence can be tested in MENA countries by using both absolute and conditional $\beta$-convergence, following the Solow model and the Barro regression (Barro, 2003). This model has been developed within the neoclassical growth theory. Although it relies on the stringent assumption of decreasing returns to scale of the reproducible factors (human and physical and capital), this equation has been widely used in the literature, notably because it provides an interesting tool for measuring real convergence. It is also increasingly used in the framework of spatial econometrics (Acraigwell and Maurin, 2011; Brasili et al., 2012; Dall'Erba and Le Gallo (2008), Ramajo et al. (2008), Soundararajan, 2013).

Basically, the model can be written as follows:

$$
\begin{aligned}
& \Delta \log G D P C=\alpha+\beta \log G D P C_{1990}+\gamma \log X+\varepsilon \\
& \varepsilon \sim N\left(0, \sigma^{2}\right)
\end{aligned}
$$

Where $\triangle \log G D P C$ is the growth of GDP per capita, GDPC $_{1990}$ is the initial GDP per capita and $\mathrm{X}$ is the vector of additional explanatory variables which take into account initial conditions. In the Solow model, these conditions can be related to saving, technology or any other variable which explains growth (institutions, infrastructure, openness, regional integration, climate, etc.). In the absolute convergence model, vector $\mathrm{X}$ is disregarded. In this 
case, if $\beta$ is negative and significant, this means that the lower the initial GDP per capita, the greater its growth. This suggests an absolute convergence which is independent from the initial conditions.

With regards to the conditional convergence model, only climate variables are available at this detailed geographical level. These data include temperature and precipitations. In an emerging literature on the relationship between climate and income, it is generally expected that the rise in temperature and the decrease in precipitations have a negative impact on growth (Dell and al. 2009). This economic loss can be explained by several channels, including mainly the reduction in agricultural productivity, but also costs due to the rise in sea level, the decrease in physical performance, migration costs, as well as the increase in morbidity, mortality, and social disruption (Pindyck, 2010).

As a consequence, the equation to be estimated for testing conditional convergence is given by:

$$
\Delta \log G D P C=\alpha+\beta \log G D P C_{1990}+\gamma_{1} \log T E M P+\gamma_{2} \log P R E C+\varepsilon
$$

The database used for temperature and precipitations is based on "Terrestrial Air Temperature and Precipitation: 1900-2008 Gridded Monthly Time Series", version 2.01 (Matsuura and Willmott 2009). This dataset provides monthly average temperature and precipitations from 1900 to 2008 for a large set of geographical cells, measured at a 1 degree longitude and 1 degree latitude resolution at a global scale. Data are spatially interpolated on the basis of station climatologies available. For all details concerning data, refer to Matsuura and Willmott (2009).

Preliminary tests based on the estimation of equation (1)' are provided in Table 2. Looking at the Moran test suggests a strong spatial autocorrelation of the error terms, with the exception of Morocco and Turkey. Consequently, the classical model is inappropriate for most geographical areas since it disregards the spatial interactions across these areas. A specific spatial model must thus be implemented. The two main spatial models are the SAR (Spatial autoregressive model) and the SEM (spatial error model). The choice between these two types of spatial models is based on the robust Lagrange Multiplier test applied on the error terms and spatial lag models. Basically, the spatial lag model (SAR) seems to be more adequate for most countries, except Egypt, for which the model with spatially correlated errors (SEM) seems preferable ${ }^{3}$.

The spatial lag model takes the following reduced form specification:

$$
\Delta \log G D P C=\left((I-\rho W)^{-1}\right)\left(\alpha+\beta \log G D P C_{1990}+\gamma_{1} \log T E M P+\gamma_{2} \log P R E C\right)+(I-\rho W)^{-1} \varepsilon
$$

Where $\rho$ measures the intensity of the spatial interaction between the regional units, and (I$\rho \mathrm{W})^{-1}$ reflects the inverse spatial transformation. It amounts to a spatial multiplier effect which has an influence on the explanatory variables.

The model with spatially correlated errors (SEM) can be written as:

$$
\triangle \log G D P C=\alpha+\beta \log G D P C_{1990}+\gamma \log X+\varepsilon
$$

\footnotetext{
${ }^{3}$ As a sensitivity analysis, both SAR and SEM models have been tested for all countries and regions. The analysis is also extended to a SARAR model which combines the SAR and SEM equations. The sign and the significance of the parameter estimates are unchanged, which is an indication of the robustness of our results. In addition, the Spatial Durbin Model (SDM) specification has also been tested. However, the likelihood statistic which tests the common factor concludes that the SDM is not the most appropriate specification, since the errors remain spatially correlated. In order to save space, the results for SARAR and SDM are not presented but are available upon request.
} 


$$
\varepsilon=\lambda \mathrm{W} \varepsilon+\mathrm{v}=(\mathrm{I}-\lambda \mathrm{W})^{-1} \mathrm{v} \text { with } v \sim N\left(0, \sigma^{2}\right)
$$

Where $\lambda$ describes the intensity of the spatial correlation across the residuals.

\section{Estimation, results and discussion}

The estimation of the appropriate model (SAR, SEM or a-spatial) for the countries considered is provided in Table 3.

A first important result is that the hypothesis of regional convergence (absolute and conditional) is generally accepted in most MENA countries, with the exception of Egypt and Morocco. This result differs to some extent with the previous a-spatial studies implemented at country level which suggest that MENA countries generally fail to converge. In the present study, considering a great number of regional areas and taking into account the spatial interactions between these areas make it possible to question the validity of the previous results. In particular, it seems that regional interactions are strong enough to spread the growth and convergence process to neighboring areas, contributing consequently to regional convergence. However, the convergence process is still slow and regional inequalities remain considerable in MENA countries. Considering for example the 808 regional areas in the absolute convergence model, the convergence speed is equal to $3 \%$ and the half time period necessary to reach the steady state is equal to 25.5 years ${ }^{4}$. This suggests that policy makers must increase their efforts to further reduce regional inequalities by implementing appropriate economic and fiscal policies.

A second interesting result is that the control variables used for calculating the conditional convergence model are generally significant and present the expected sign. As a matter of fact, a rise in temperature or a decrease in rainfalls leads to a decrease in GDP per capita. These results are in accordance with the new empirical results which link climate to the real economy (Dell et al., 2009). Consequently, climate change in MENA countries is likely to have detrimental effects on real income and may delay the convergence process which has been identified in this paper.

Due to data limitation at detailed geographical level, the previous analysis is limited to three independent variables only, i.e. the initial income, temperature and precipitations. In order to tackle the potential omitted variable bias, a final robustness analysis can be implemented by estimating the model while using a larger set of variables available at national level. The choice of the appropriate variables in convergence models is widely discussed in the literature (see for instance Sala-i-Martin (2004)). Based on this literature, the extended model presented here first includes variables related to human capital and technology. These are education (secondary schooling enrolment rate. Source: WDI) and R\&D (research and development expenditures as a percentage of GDP, source: WDI). A second set of variables is related to trade and specialization, i.e. the UNCTAD inter-industry specialization and trade dissimilarity indexes. Third, transports and communications are measured by the percentage of paved road and the number of telephone lines for 1000 inhabitants (source: WDI). Finally the role of the State is measured by the share of government in consumption (source: Penn World Tables).

\footnotetext{
${ }^{4}$ We recall that the convergence speed is equal to : $-\ln (1+T \beta) / T$; the half time is equal to: $-\ln (2) / \ln (1+\beta)$
} 
Table 2. Preliminary tests applied on the classical (a-spatial model)

\begin{tabular}{|c|c|c|c|c|c|c|c|}
\hline ABSOLUTE & All Areas & Algeria & Egypt & Maghreb & Mashrek & Morocco & Turkey \\
\hline$\alpha$ & $\begin{array}{l}13.8922 \\
(0.0287)^{* *}\end{array}$ & $\begin{array}{l}3.1471 \\
(0.155)\end{array}$ & $\begin{array}{l}3.7801 \\
\left(2.13 .10^{-8}\right)^{* * *}\end{array}$ & $\begin{array}{l}2.521 \\
(0.0035)^{* * *}\end{array}$ & $\begin{array}{l}4.2312 \\
\left(2.3 .10^{-2}\right)^{* *}\end{array}$ & $\begin{array}{l}1.8271 \\
\left(2.10^{-16}\right)^{* * *}\end{array}$ & $\begin{array}{l}2.054 \\
\left(2.10^{-16}\right)^{* * *}\end{array}$ \\
\hline$\beta$ & $\begin{array}{l}-0.040 \\
(0.0613)^{*}\end{array}$ & $\begin{array}{l}-0.0272 \\
(0.352)\end{array}$ & $\begin{array}{l}-0.0169 \\
(0.653)\end{array}$ & $\begin{array}{l}-0.0345 \\
(0.0054)^{* * *}\end{array}$ & $\begin{array}{l}-0.0512 \\
(0.0012)^{* * * *}\end{array}$ & $-1.04 .10^{-7}(0.704)$ & $-0.025(0.0043)^{* * *}$ \\
\hline AIC & 1707.4 & 1239.8 & 352.64 & 1220.31 & 930.45 & 267.45 & 299.123 \\
\hline$I_{M^{-}} E r r$ & $\begin{array}{l}0.439 \\
\left(2.2 .10^{-8}\right)^{* * *}\end{array}$ & $\begin{array}{l}0.366 \\
\left(2.2 .10-{ }^{16}\right)^{* * *}\end{array}$ & $\begin{array}{l}0.2386 \\
\left(4.2 \cdot 10^{-7}\right)^{* * *}\end{array}$ & $\begin{array}{l}0.5351 \\
\left(2.2 .10-{ }^{16}\right)^{* * *}\end{array}$ & $\begin{array}{l}0.43512 \\
\left(2 \cdot 2 \cdot 10-{ }^{16}\right)^{\text {**** }}\end{array}$ & $\begin{array}{l}0.1253 \\
(0.491)\end{array}$ & $\begin{array}{l}-0.0213 \\
(0.5262)\end{array}$ \\
\hline RLMerr & $\begin{array}{l}6.1454 \\
\left(5.2 .10^{-4}\right)^{* * *}\end{array}$ & $\begin{array}{l}0.0969 \\
(0.7556)\end{array}$ & $\begin{array}{l}0.1151 \\
(0.0844) *\end{array}$ & $\begin{array}{l}4.5214 \\
(0.0252)^{* *}\end{array}$ & $\begin{array}{l}3.5214 \\
(0.0752)^{*}\end{array}$ & - & \\
\hline RLMlag & $\begin{array}{l}14.4521 \\
(0.0018)^{\text {*** }}\end{array}$ & $\begin{array}{l}0.2465 \\
(0.6196)\end{array}$ & $\begin{array}{l}0.0282 \\
(0.8666)\end{array}$ & $\begin{array}{l}8.1251 \\
(0.0052)^{* * *}\end{array}$ & $\begin{array}{l}7.2145 \\
(0.0235)^{* *}\end{array}$ & - & - \\
\hline CONDITIONAL & All Areas & Algeria & Egypt & Maghreb & Mashrek & Morocco & Turkey \\
\hline$\alpha$ & $\begin{array}{l}5.22084 \\
\left(2.2 .10-^{16}\right)^{* * *}\end{array}$ & $\begin{array}{l}2.931330 \\
(0.202)\end{array}$ & $\begin{array}{l}3.7582096 \\
\left(1.06 .10-^{6}\right)^{* * *}\end{array}$ & $\begin{array}{l}1.2514 \\
(0.0013)^{* * *}\end{array}$ & $\begin{array}{l}2.1102 \\
(0.0001)^{* * *}\end{array}$ & $\begin{array}{l}1.827 \\
\left(2.10-{ }^{16}\right)^{* * * *}\end{array}$ & $\begin{array}{l}2.054 \\
\left(2.2 .10-^{16}\right)^{* * *}\end{array}$ \\
\hline$\beta$ & $\begin{array}{l}-0.32843 \\
\left(7.2 .10-^{16}\right)^{* * *}\end{array}$ & $\begin{array}{l}-0.2374 \\
(0.442)\end{array}$ & $\begin{array}{l}-0.0104 \\
(0.8041)\end{array}$ & $\begin{array}{l}-0.0215 \\
(0.0011)^{* * *}\end{array}$ & $\begin{array}{l}-0.0152 \\
(0.0013)^{* * *}\end{array}$ & $\begin{array}{l}8.3 \cdot 10-^{2} \\
(0.778)\end{array}$ & $\begin{array}{l}-3.508 .10-^{7} \\
(0.00285)^{* * *}\end{array}$ \\
\hline$\gamma_{1}$ & $\begin{array}{l}-0.93334 \\
\left(2.10^{-16}\right)^{* * *}\end{array}$ & $\begin{array}{l}-0.701664 \\
(0.690)\end{array}$ & $\begin{array}{l}0.1652339 \\
(0.0116)^{* *}\end{array}$ & $\begin{array}{l}-3.1245 \\
(0.0151)^{* *}\end{array}$ & $\begin{array}{l}-5.4512 \\
(0.0421)^{* *}\end{array}$ & $\begin{array}{l}1.684 \mathrm{e}-07 \\
(0.554)\end{array}$ & $\begin{array}{l}2.958 .10-^{7} \\
(0.2247)\end{array}$ \\
\hline$\gamma_{2}$ & $\begin{array}{l}1.05391 \\
(0.0157)^{* *}\end{array}$ & $\begin{array}{l}-0.004329 \\
(0.836)\end{array}$ & $\begin{array}{l}-0.0008 \\
(0.0373)^{* *}\end{array}$ & $\begin{array}{l}0.5213 \\
(0.0052)^{* * *}\end{array}$ & $\begin{array}{l}0.2314 \\
(0.0524)^{*}\end{array}$ & $\begin{array}{l}2.5 .10-^{6} \\
(0.222)\end{array}$ & $\begin{array}{l}8.7 .10-^{7} \\
(0.865)\end{array}$ \\
\hline AIC & 1627.7 & 1243.6 & 840.25 & 1510.23 & 1315.45 & 0.0562 & 0.0912 \\
\hline$I_{M}-E r r$ & $\begin{array}{l}0.3553 \\
\left(2.2 .10-{ }^{16}\right)^{* * *}\end{array}$ & $\begin{array}{l}0.1423 \\
\left(1.3 .10-^{6}\right)^{* * *}\end{array}$ & $\begin{array}{l}0.149 \\
(0.0001)^{* * *}\end{array}$ & $\begin{array}{l}0.7541 \\
\left(2.10-^{16}\right)^{* * *}\end{array}$ & $\begin{array}{l}0.5214 \\
\left(2.2 .10-{ }^{16}\right)^{* * *}\end{array}$ & $\begin{array}{l}0.1068 \\
(0.1229)\end{array}$ & $\begin{array}{l}-0.013 \\
(0.416)\end{array}$ \\
\hline RLMerr & $\begin{array}{l}7.501 \\
(0.0061)^{* * *}\end{array}$ & $2.2417(0.1343)$ & $\begin{array}{l}16.7661 \\
(0.00092)^{* * *}\end{array}$ & $\begin{array}{l}3.1245 \\
(0.0512)^{*}\end{array}$ & $\begin{array}{l}3.4152 \\
(0.0713)^{*}\end{array}$ & - & - \\
\hline RLMlag & $\begin{array}{l}12.5259 \\
(0.0004)^{* * *}\end{array}$ & $2.8728(0.0900)^{*}$ & $\begin{array}{l}10.0821 \\
(0.0014)^{* * *}\end{array}$ & $\begin{array}{l}5.1245 \\
(0.0022)^{* * *}\end{array}$ & $\begin{array}{l}6.1050 \\
(0.0120)^{* *}\end{array}$ & - & - \\
\hline
\end{tabular}

Note: $* * *, * *, *$ significant at $1 \%, 5 \%$ and $10 \%$ respectively; AIC : Akaïke information criteria; lm-err: Moran test; RLMerr and RLMlag are respectively the robust

Lagrange Multiplier test applied on the error terms and spatial lag models 
Table 3. Estimation results

\begin{tabular}{|c|c|c|c|c|c|c|c|}
\hline ABSOLUTE & $\begin{array}{l}\text { All Areas } \\
\text { SAR }\end{array}$ & $\begin{array}{l}\text { Algeria } \\
\text { SAR }\end{array}$ & $\begin{array}{l}\text { Egypt } \\
\text { SEM }\end{array}$ & $\begin{array}{l}\text { Maghreb } \\
\text { SAR }\end{array}$ & $\begin{array}{l}\text { Mashrek } \\
\text { SAR }\end{array}$ & $\begin{array}{l}\text { Morocco } \\
\text { a-spatial }\end{array}$ & $\begin{array}{l}\text { Turkey } \\
\text { a-spatial }\end{array}$ \\
\hline$\alpha \alpha$ & $\begin{array}{l}3.4369 \\
\left(2.10-^{16}\right)^{* * * *}\end{array}$ & $\begin{array}{l}2.4799 \\
\left(1.9 .10-^{7}\right)^{* * * *}\end{array}$ & $\begin{array}{l}3.6636 \\
\left(4.72 .10-^{7}\right)^{* * *}\end{array}$ & $\begin{array}{l}2.1212 \\
(0.004) * * *\end{array}$ & $\begin{array}{l}4.5181 \\
\left(2.2 .10^{-5}\right)^{* * *}\end{array}$ & $\begin{array}{l}1.8271 \\
\left(2.10^{-16}\right)^{* * * *}\end{array}$ & $\begin{array}{l}2.054 \\
\left(2.10^{-16}\right)^{* * * *}\end{array}$ \\
\hline$\beta$ & $\begin{array}{l}-0.0249 \\
\left(8.9 .10-^{12}\right)^{* * *}\end{array}$ & $\begin{array}{l}-0.0898 \\
\left(1.9 .10-^{5}\right)^{* * *}\end{array}$ & $\begin{array}{l}0.0254 \\
(0.5534)\end{array}$ & $\begin{array}{l}-0.0341 \\
(0.0014)^{* * *}\end{array}$ & $\begin{array}{l}-0.0521 \\
(0.0008)^{* * *}\end{array}$ & $\begin{array}{l}-1.04 .10^{-7} \\
(0.704)\end{array}$ & $\begin{array}{l}-0.025 \\
(0.0043)^{* * *}\end{array}$ \\
\hline$\rho(\lambda)$ & $\begin{array}{l}0.74802 \\
\left(2.2 \cdot 10-^{16}\right)^{* * *}\end{array}$ & $\begin{array}{l}0.72187 \\
\left(2.2 .10-{ }^{16}\right)^{* * *}\end{array}$ & $\begin{array}{l}0.5125 \\
(0.000)^{* * *}\end{array}$ & $\begin{array}{l}0.8512 \\
\left(2.2 .10-^{16}\right)^{\text {**** }}\end{array}$ & $\begin{array}{l}0.7512 \\
\left(2.2 \cdot 10-^{16}\right)^{* * *}\end{array}$ & - & - \\
\hline $\log L$ & -714.315 & -268.583 & -166.098 & -650.12 & -412.52 & - & - \\
\hline AIC & 1436.6 & 545.17 & 340.2 & 1010.45 & 715.46 & - & - \\
\hline CONDITIONNAL & All Areas & Algeria & $\overline{\text { Egypt }}$ & Maghreb & Mashrek & Morocco & Turkey \\
\hline$\alpha$ & $\begin{array}{l}2.657344 \\
\left(2.2 .10-^{16}\right)^{* * * *}\end{array}$ & $\begin{array}{l}2.3570 \\
(0.277)\end{array}$ & $\begin{array}{l}2.05404 \\
(0.0117)^{* *}\end{array}$ & $\begin{array}{l}1.0235 \\
(0.0235)^{* *}\end{array}$ & $\begin{array}{l}1.1452 \\
(0.0052)^{\text {**** }}\end{array}$ & $\begin{array}{l}1.827 \\
\left(2.10-{ }^{16}\right)^{* * *}\end{array}$ & $\begin{array}{l}2.054 \\
\left(2.2 .10-^{16}\right)^{* * *}\end{array}$ \\
\hline$\beta$ & $\begin{array}{l}-0.0233 \\
\left(1.4 .10-{ }^{12}\right)^{* * *}\end{array}$ & $\begin{array}{l}-0.0258 \\
(0.0385)^{* *}\end{array}$ & $\begin{array}{l}-0.00169 \\
(0.96501)\end{array}$ & $\begin{array}{l}-0.0123 \\
(0.0120)^{* *}\end{array}$ & $\begin{array}{l}-0.0235 \\
(0.0077)^{* * *}\end{array}$ & $\begin{array}{l}8.3 \cdot 10-^{2} \\
(0.778)\end{array}$ & $\begin{array}{l}-3.508 .10-^{7} \\
(0.00285)^{* * *}\end{array}$ \\
\hline$\gamma_{1}$ & $\begin{array}{l}-0.3343 \\
(0.0001)^{* * *}\end{array}$ & $\begin{array}{l}-0.04184 \\
(0.0799)^{*}\end{array}$ & $\begin{array}{l}0.08785 \\
(0.14694)\end{array}$ & $\begin{array}{l}-2.0052 \\
(0.0081)^{* * *}\end{array}$ & $\begin{array}{l}-5.0025 \\
(0.0152)^{* *}\end{array}$ & $\begin{array}{l}1.684 \mathrm{e}-07 \\
(0.554)\end{array}$ & $\begin{array}{l}2.958 .10-^{7} \\
(0.2247)\end{array}$ \\
\hline$\gamma_{2}$ & $\begin{array}{l}0.1292 \\
(0.0717)^{*}\end{array}$ & $\begin{array}{l}-0.0005 \\
(0.0681)^{*}\end{array}$ & $\begin{array}{l}0.5001 \\
(0.0483)^{* *}\end{array}$ & $\begin{array}{l}0.20151 \\
(0.0091)^{* * *}\end{array}$ & $\begin{array}{l}0.20812 \\
(0.0424)^{\text {** }}\end{array}$ & $\begin{array}{l}2.5 .10-{ }^{6} \\
(0.222)\end{array}$ & $\begin{array}{l}8.7 \cdot 10-{ }^{7} \\
(0.865)\end{array}$ \\
\hline$\rho(\lambda)$ & $\begin{array}{l}0.6869 \\
\left(2.2 .10-^{16}\right)^{* * *}\end{array}$ & $\begin{array}{l}0.42154 \\
\left(4.3 .10^{5}\right)^{* * *}\end{array}$ & $\begin{array}{l}0.44342 \\
(0.0022)^{* * *}\end{array}$ & $\begin{array}{l}0.6652 \\
\left(2.2 .10-^{16}\right)^{* * *}\end{array}$ & $\begin{array}{l}0.56121 \\
\left(2.2 .10-{ }^{16}\right)^{* * *}\end{array}$ & - & - \\
\hline $\log L$ & -705.6942 & -608.4452 & -164.8151 & -565.165 & -156.2514 & - & - \\
\hline AIC & 1423.4 & 1228.9 & 341.63 & 1400.560 & 1245.526 & - & - \\
\hline
\end{tabular}

LogL: value of the log-likelihood function 
The model is estimated for the period 1990 to 2008 for the 10 MENA countries described above. This is a panel data model which has been estimated with three alternative estimators: Hausman and Taylor (HT, which is appropriate to address endogeneity), the Baltagi-Wu (BW) GLS which assumes panel autocorrelation of the residuals, as well as the GLS for heteroskedastic error structures (HGLS).

Interestingly, Table 4 provides results which correlate those presented in Table 3. In particular, the convergence process is slow and climate variables play a significant role in explaining GDP per capita. This confirms the robustness of the spatial models presented previously. However, GDP per capita is also explained by the additional variables introduced in Table 4. Indeed, higher education and technology levels both increase GDP per capita. Inter-industry specialization is detrimental to growth in MENA country as well as trade dissimilarity. This can be explained by the fact that MENA countries are specialized in standard products (agriculture, textile) and these specializations are dissimilar to international demand. Finally, transport and communication also play a determinant role for explaining growth and convergence.

Table 4. Results corresponding to the extended model

\begin{tabular}{lrrr}
\hline \hline & \multicolumn{1}{c}{ HT } & BW GLS & \multicolumn{1}{l}{ HGLS } \\
\hline \hline Initial income ( $\beta$ ) & $-0.026^{* * *}$ & $-0.026^{* * *}$ & $-0.034^{* * *}$ \\
Climate & & & \\
Température & $-0.013^{* *}$ & $-0.039^{* *}$ & $-0.011^{* *}$ \\
Precipitations & $0.001^{* *}$ & $0.001^{* *}$ & $0.001^{* *}$ \\
Human Capital and Technology & & & \\
Education & $0.057^{* *}$ & $0.044^{* *}$ & $0.059^{* *}$ \\
R\&D & $0.037^{* *}$ & $0.036^{* *}$ & $0.047^{* *}$ \\
Trade, specialization and openness & & & $-0.013^{*}$ \\
Inter-industry specialization (endogenous) & $-0.015^{* *}$ & $-0.015^{* *}$ & $-0.022^{* * *}$ \\
Trade Dissimilarity & $-0.023^{* * *}$ & $-0.022^{* * *}$ & \\
Transports and communications & & & $0.0172^{* * *}$ \\
Roads (endogenous) & $0.0165^{* * *}$ & $0.0165^{* * *}$ & $0.02^{* *}$ \\
Telephone (endogenous) & $0.018^{* *}$ & $0.018^{* *}$ & \\
Other & & & 0.0006 \\
government share in consumption & 0.0008 & 0.0009 & - \\
Tests & & & - \\
Endogeneity (Hausman) & 3.52 & - & - \\
Heteroskedasticity (White) & 145.385 & - & - \\
Autocorrelation (Rho) & 0.128589 & - & - \\
Multicolinearity (VIF) & 1.44 & - & \\
\hline \hline
\end{tabular}

Note: $* * *, * *, *$ : significant at $1 \%, 5 \%$ and $10 \%$ respectively

Acknowledgements. We would like to thank the reviewers for their very helpful comments. 


\section{References}

Acraigwell, R. and A. Maurin (2011) Are Caribbean countries diverging or converging? Evidence from spatial econometrics, Journal of Business, Finance and Economics in Emerging Economies, 6, 161-206.

Barro, R. (2003) Determinants of economic growth in a panel of countries, Annals of Economics and Finance, 4, 231-274.

Brasili, C., Bruno, F. and Saguatti, A. (2012) Regional disparities between economic and geographical periphery, Statistica, 3, 299-316.

Dall'Erba, S. and Le Gallo, J. (2008) Regional convergence and the impact of European structural funds over 1989-1999: a spatial econometric analysis, Papers in Regional Science, 87(2), 219-244.

Dell, M., Jones, B. and Olken, B. (2009) Temperature and income: reconciling new crosssectional and panel estimates, American Economic Review, 99(2), 198-204.

Erlat, H. (2007) Time series approaches to testing income convergence in MENA countries, in: Topics in Middle Eastern and North African Economies, Proceedings of the Middle-East Economic Association, 9, 355-378.

Guétat, I. and Serranito, F. (2007) Income convergence within MENA countries: a panel unit root approach, Quarterly Review of Economics and Finance, 46, 615-706.

Guétat, I. and Serranito, F. (2010) Convergence et rattrapage technologique: un test par les séries temporelles dans le Cas de Pays de la région MENA, Revue d'Economie du Développement, 2, 5-45.

Hammouda, H., Karingi,, S., Njuguna, A. and Sadni-Jallab, M. (2009) Why doesn't regional integration improve income convergence in Africa?, African Development Review, 21(2), 291-330.

Li, H., Clader, C.A. and Cressie, N. (2007) Beyond Moran's I: testing for spatial dependence based on the spatial autoregressive model, Geographical Analysis, 39, 357-375.

Matsuura, K. and Willmott, C. (2009) Terrestrial precipitation and temperature: 1900-2008 gridded monthly time series, Center for Climatic Research, Department of Geography.

Péridy, N. and Bagoulla, C. (2012) An analysis of real convergence and its determinants: evidence from MENA countries, Journal of Economic Integration, 27(1), 80-114.

Pesaran, M. (2007) A pair-wise approach to testing for output and growth convergence, Journal of Econometrics, 138, 312-355.

Pindyck, R. (2010) Modeling the impact of warming in climate change economics, NBER working Paper, 15692.

Ramajo, J., Marquez, M., Hewings, G. and Salinas, M. (2008) Spatial heterogeneity and interregional spillovers in the European Union: do cohesion policies encourage convergence across regions?, European Economic Review, 52, 551-567.

Rey, S. (2005) Convergence réelle et convergence nominale dans les pays de la région MENA, FEMISE Report 22-36, Obstacles to South-South Integration, to trade and to foreign direct investment: the MENA countries case, ch.4, 194-248.

Sala-i-Martin, X. (2004) Determinants of long-term growth: a Bayesian averaging of classical estimates (BACE) approach, American Economic Review, 94(4), 814-835.

Soundararajan, P. (2013) Regional income convergence in India: a Bayesian spatial Durbin model approach, MPRA Paper No. 48453. 


\section{Appendix}

Table A.1. Moran, Geary and APLE statistics based on the second-order contiguity matrix

\begin{tabular}{|c|c|c|c|c|}
\hline & $\begin{array}{l}\text { Number of } \\
\text { regional units }\end{array}$ & Moran & $\overline{\text { Geary }}$ & 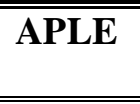 \\
\hline $\begin{array}{l}\text { All areas } \\
\text { (MENA) }\end{array}$ & 808 & $\begin{array}{l}0.3214 \\
\left(2.2 .10^{-7}\right)^{* * *}\end{array}$ & $\begin{array}{l}0.4154 \\
\left(2.2 .10^{-8}\right)^{* * *}\end{array}$ & 0.6511 \\
\hline Algeria & 255 & $\begin{array}{l}0.2745 \\
\left(2.3 .10^{-13}\right)^{* * * *}\end{array}$ & $\begin{array}{l}0.6512 \\
\left(5.78 .10^{-}\right. \\
12)^{* * * *}\end{array}$ & 0.5015 \\
\hline Egypt & 106 & $\begin{array}{l}0.1252 \\
(0.0012)^{* * * *}\end{array}$ & $\begin{array}{l}0.6451 \\
(0.008)^{* * *}\end{array}$ & 0.4729 \\
\hline Libya & 71 & $\begin{array}{l}0.2814 \\
\left(2.2 .10^{-5}\right)^{* * * *}\end{array}$ & $\begin{array}{l}0.514 \\
\left(2.2 .10^{-6}\right)^{* * *}\end{array}$ & 0.5645 \\
\hline Morocco & 81 & $\begin{array}{l}0.1142 \\
\left(2.2 .10^{-14}\right)^{* * *}\end{array}$ & $\begin{array}{l}0.4045 \\
\left(1.89 .10^{-}\right. \\
\left.{ }^{3}\right)^{* * * *}\end{array}$ & 0.4509 \\
\hline Turkey & 102 & $\begin{array}{l}0.5412 \\
\left(2.2 .10^{-12}\right)^{* * *}\end{array}$ & $\begin{array}{l}0.1412 \\
\left(2.2 .10^{-13}\right)^{* * *}\end{array}$ & 0.7948 \\
\hline Mashrek & 171 & $\begin{array}{l}0.34521 \\
\left(3.45 .10^{-8}\right)^{* * *}\end{array}$ & $\begin{array}{l}0.4912 \\
\left(7.2 \cdot 10^{-8}\right)^{* * *}\end{array}$ & 0.6012 \\
\hline Maghreb & 537 & $\begin{array}{l}0.3075 \\
\left(2.2 .10^{-16}\right)^{* * *}\end{array}$ & $\begin{array}{l}0.6912 \\
\left(2.2 .10^{-16}\right)^{* * *}\end{array}$ & 0.69415 \\
\hline
\end{tabular}

Table A.2: Moran, Geary and APLE statistics based on the nearest neighbor matrix

\begin{tabular}{|c|c|c|c|c|}
\hline & $\begin{array}{l}\text { Number of } \\
\text { regional } \\
\text { units }\end{array}$ & Moran & Teary & $\overline{~ A P L E ~}$ \\
\hline $\begin{array}{l}\text { All areas } \\
\text { (MENA) }\end{array}$ & 808 & $\begin{array}{l}0.3712 \\
\left(2 \cdot 2 \cdot 10^{-16}\right)^{* * * *}\end{array}$ & $\begin{array}{l}0.4845 \\
\left(3.4 .10^{-8}\right)^{* * *}\end{array}$ & 0.5745 \\
\hline Algeria & 255 & $\begin{array}{l}0.2502 \\
\left(2.1 .10^{-10}\right)^{* * * *}\end{array}$ & $\begin{array}{l}0.6541 \\
\left(2.78 .10^{-8}\right)^{* * *}\end{array}$ & 0.5515 \\
\hline Egypt & 106 & $\begin{array}{l}0.1645 \\
(0.0005)^{* * * *}\end{array}$ & $\begin{array}{l}0.4785 \\
(0.0105)^{* *}\end{array}$ & 0.37451 \\
\hline Libya & 71 & $\begin{array}{l}0.23451 \\
\left(4.5 \cdot 10^{-3}\right)^{* * * *}\end{array}$ & $\begin{array}{l}0.6121 \\
\left(2.2 .10^{-8}\right)^{* * *}\end{array}$ & 0.4512 \\
\hline Morocco & 81 & $\begin{array}{l}0.2145 \\
\left(2 \cdot 2 \cdot 10^{-16}\right)^{* * *}\end{array}$ & $\begin{array}{l}0.354 \\
\left(2.54 .10^{-4}\right)^{* * *}\end{array}$ & 0.4785 \\
\hline Turkey & 102 & $\begin{array}{l}0.5124 \\
\left(1.1 .10^{-8}\right)^{* * *}\end{array}$ & $\begin{array}{l}0.3545 \\
\left(3.5 .10^{-7}\right)^{* * *}\end{array}$ & 0.7589 \\
\hline Mashrek & 171 & $\begin{array}{l}0.4512 \\
\left(2 \cdot 2 \cdot 10^{-16}\right)^{* * *}\end{array}$ & $\begin{array}{l}0.39451 \\
\left(4.5 .10^{-5}\right)^{* * *}\end{array}$ & 0.6875 \\
\hline Maghreb & 537 & $\begin{array}{l}0.4812 \\
\left(2 \cdot 2 \cdot 10^{-16}\right)^{* * *}\end{array}$ & $\begin{array}{l}0.39451 \\
\left(2.9 .10^{-10}\right)^{* * *}\end{array}$ & 0.7185 \\
\hline
\end{tabular}

